\title{
Impact of Covid-19 on Garment Sector in Bangladesh
}

\author{
MD KHADEMUL ISLAM
}

\author{
Aligarh Muslim University \\ Department of Commerce \\ DOI: 10.29322/IJSRP.10.11.2020.p10716 \\ http://dx.doi.org/10.29322/IJSRP.10.11.2020.p10716
}

\begin{abstract}
Bangladesh is a developing country with remarkable economic growth (growing around 7\% average growth rate last 10 years). The recent COVID-19 pandemic has caused colossal damage in this emerging South Asian nation most notably in public health, social well-being, and Education in Bangladesh. This paper aims to study the Coronavirus (Covid-19) consequences to the garment sector of Bangladesh and the garment workers. This virus has had a detrimental impact on the Garment's owner and the workers, as a result, find themselves unemployed, with many exhausting their savings they stare at possible starvation and return to perpetual poverty. Experts have opined that the current scenario will continue to exist for now and is likely to cause more deaths, taking a toll on the already miserable condition of the economy, public health and employment; causing much distress among the people mentally and physically. Adding to woes the export of Ready-made Garment (RMG) is also less than the expected which is a serious cause of concern. Owing to this, foreign direct investment (FDI) and Foreign Institutional Investment (FII) has taken a hit with the outcome being a trade deficit. The domestic currency has weakened as a consequence of foreign currency. The various financial stimulus or relief should be taken to tackle the problem like subsidies, certain tax relief in the response to the COVID-19 pandemic and import duty exemption on medical and protective equipment.
\end{abstract}

Index Terms- COVID-19, Garment Sector in Bangladesh, History, Impact of Covid-19 on Garment Sector.

\section{INTRODUCTION}

COVID-19 today has gripped the attention all around the world due to its deadly impact rendering the World to a standstill. It is subsequently named after SARS-Cov-2. Some experts believe that its origin is from the wholesale food market at Hubei province in China. Most of the infected persons in its incipient stage were related to this market such as stall owners, retailers, employees, and consumers. Later this province was declared as the source of the Covid-19 outbreak, and as a result in January 2020 market had been closed. After a month, the virus started spreading to other countries notably in the USA, INDIA, BRAZIL, ARGENTINA, RUSSIA, and SPAIN. This virus is contagious and spreads typically from person to person by sneezing, coughing (droplet transmission) and touching a contaminated surface. Many times, the infected person can be asymptomatic i.e. they could already be infected with the virus but symptoms may not be visible. Symptoms generally show up in about 14 days and transmission is hence possible before having any symptoms. Recommended precautionary measures such as washing hands with hand wash, using musk, avoid handshake, maintaining one-meter distance, self-isolation of 14 days for those who travelled to infected areas or if someone is suspected as a possible victim are prescribed. The origins can be traced back to China but the virus has suffused to almost every country today. According to research, published in the Lancet, the research predicted that $6.4 \%$ of Covid-19 infected people older than 60 could die, but this could rise to $13.4 \%$ for those who are above 80 years of age. As of 20 October 2020, the USA is having the highest number of cases followed by India, Brazil, Russia, Spain, Colombia, and Bangladesh enlisted as 16 positions out of 216 countries. 
TABLE-1: Number of COVID cases and Death due to Covid-19

\begin{tabular}{|l|l|l|l|l|}
\hline Country & Total Cases & $\begin{array}{l}\text { Total } \\
\text { REVOVERED }\end{array}$ & Total Deaths & Total tests \\
\hline USA & $8,468,223$ & $5,513,584$ & $2,25,451$ & 127138924 \\
\hline India & $7,644,979$ & $6,784,742$ & $1,15,879$ & 96116771 \\
\hline Brazil & $5,255,277$ & $4,681,659$ & 15,4327 & $17,900,000$ \\
\hline Russia & $1,431,635$ & $1,085,608$ & 24,635 & $54,675,096$ \\
\hline Spain & $1,015,795$ & N/A & 33,992 & $15,503,165$ \\
\hline Argentina & $1,002,662$ & 803,965 & 26,716 & $2,626,406$ \\
\hline Colombia & 965,883 & 867,961 & 29,102 & $4,467,051$ \\
\hline
\end{tabular}

\section{Source: WorldoMeter}

To deal with this pressing scenario, Vaccines must be developed. Many countries are working on it with an enormous amount of budget but there is uncertainty about whether the cure would be developed in time. Now every country is well acquainted with the challenges this pandemic brings specifically on the economic front. Major Economies of the world have revised their growth estimates which are set to fall drastically. For instance, the Japanese economy has entered into a recession due to dampening consumer spending and exports. The ill-effects are more appalling in developing economies like that of Bangladesh. GDP of Bangladesh depends on Agriculture, industry, financial institution. In October 2019, the International Monetary Fund (IMF) predicted a 7.4\% growth rate for the Financial year of 2020-2021. Due to Covid-19, in mid of April 2020, (IMF) has revised the growth estimates and now says Bangladesh will be having only $2 \%$ GDP growth in this Financial year (2020-2021). Because most of the people of Bangladesh depend on agriculture which is having 3rd largest contributor to GDP after Service and industry. Moreover, the financial market is being threatened by a massive financial crisis. Dhaka Stock Exchange (DSE) and Chattogram Stock Exchange (CSE) is the country's major bourse being collapsed in this situation and financial institutions got liquidity crises because of financial instrument monetization. On the other hand, employees are losing their job and others are not getting a proper salary. One-third of Garments workers have lost their job because of declining foreign order amid this Pandemic situation. Bangladesh has emerged the opportunity to lead the garments manufacturing (RMG) sector. Bangladesh is the second-best readymade garment exporter after China, accounting for $81 \%$ of the total export rate and contributes nearly $20 \%$ to Gross Domestic Products (GDP) from textile and apparel. This sector employs approximately 20 million workers in the country. Bangladesh had the plan to get into a middle-income country by the forthcoming financial year but Covid-19 impact on garments manufacturing (RMG) lifted the dream.

\section{LITERATURE REVIEW}

Only a few papers have been published regarding this pandemic situation and the current economic condition of Bangladesh. Because of the current economic disruption everyone being cursed whether businessmen, service holders, students, or unemployed youth. World Bank shows a data TK 500 (USD 5.92) could earn by only 15\% population of Bangladesh. On 6 March 2020, the Asian Development Bank (ADB) assumed that the impact of Covid-19 on the economy would be laid off by 894,930 workers in Bangladesh. Data from Kabir Humayun, Maple Myfanwy, and Usher Kim stated that from 13 March to 5 April $202014 \%$ of the total 2675 respondents weren't having enough food reserve at their home, only $29 \%$ had enough food to survive for one to three days. They also pointed out; Covid-19 outbreak warns a potential hunger that could be like the greatest humanitarian crisis since World war-2. Sen Shuvo, Neel Antara, Sen Sushmita, and Chowdhury Sunny ascertained the workers are passing through a crucial time with the financial crisis and they started protesting on the street for their daily remuneration. They also added that the treatment facility is not good enough for the patients. For instance, only 500 Intensive Care Unit (ICU) facility available for approximately 170 Million peoples. So, most people won't get enough treatment in this pandemic situation. Begum Momotaj, Farid Sarkar, Barua Swarup, and dr. Alam Jahangir Mohammad analyzed the Socio-Economic condition of the Agriculture Sector, Industrial Sector, Service Sector, Health effects, and Education effects. All the major sector has been facing various problems due to Covid-19. The poultry sector worrying to get losses of about tk1150 crore to sales between 20 March 2020 and 4 April 2020. Bangladesh Poultry Industries Central Council (BPICC) stated that the sale of eggs and chicken has already deteriorated. The commerce minister Tipu Munshi told CNBC news, the world's second-largest clothing exporter (Bangladesh) has cancelled numerous orders and this could be led to serious problems in the future. The education sector is also widely affected due to this pandemic; on October $7^{\text {th }}, 2020$ the Bangladesh Govt. has decided there will be no examinations. A total of 1,365,689 students were supposed to seat for the pen and paper Higher Secondary Certificate (H.S.C) exam. Dipu Moni assured that the students will be passed H.S.C exams according to the mean of Junior School Certificate (J.S.C) and the Senior Secondary Certificate (S.S.C) examination's Grade Point Average (GPA). 
To review all the papers it might be right to say Bangladesh needs help from affluence persons and Govt. should put an additional budget on Public expenditure and should decrease the Public revenue to support the corporate sectors and Small and Medium Enterprises (SMEs) in Bangladesh.

\section{THE OBJECTIVE OF THE STUDY}

The major objective of this study is to give an overview of the Garment Sector in Bangladesh with its evolution and current scenario of economic condition. The main aspects of the Garment Industry and Covid-19 impact on it has been examined and cited with short descriptions-

1. To discuss the Garment Sector's contribution to Gross Domestic Product (GDP) of emerging Bangladesh.

2. Evolution of the Garment industry in Bangladesh and the rapid escalation of this sector.

3. A short description of COVID-19 in Bangladesh and the rest of the world.

4. The economic slowdown of Bangladesh due to the downturn of Revenue of the Garment Sector and unavailability of monetary fund and loan of the garment sectors

5. The safety issue of the workers, awareness of precautions and Jobless workers rate and their family condition with hunger

6. A possible solution to the current economic situation

\section{RESEARCH METHODOLOGY}

To understand the forthcoming economic condition and the Covid-19 situation can't be predicted as the scenario is changing day by day. Thus, the main data has been collected from secondary sources such as various journals, internet, newspaper, and different national \& international organizations (BGMEA, EPB, WTO, WHO, IMF, and World Bank). All the data has been presented in Qualitative Methods.

\section{A. Sources of Data}

To completion of this report primary and secondary data has been used from different sources.

\section{B. Primary Data}

Through physical conversation with the respective officers and the workers of the garment sector.

\section{Secondary data}

1. Various data sources such as Bangladesh Garment Manufacturers and Exporters Association (BGMEA), International Monetary Fund (IMF), World Bank (WB), Bangladesh Bank (BB), Dhaka stock exchange (DSE), Chattogram Stock Exchange (CSE), Export Promotion Bureau (EPB), etc.

2. Internet browsing through website searching and financial year's report from various organizations.

3. Authentic published materials books and articles

\section{Analysis of data}

Various Tables and Figures have been used for analyzing the collected data and a simple time series analysis is used for demonstrating the trend of export and contribution of export to the GDP in Bangladesh.

\section{ANALYSIS AND FINDING}

The industrial sector has an emergent role in Bangladesh's economy and contribution to Gross Domestic Product (GDP) is progressively increasing. According to the Bangladesh Bureau of Statistics (BBS), the Industry sector is contributing 31.15 percent for the financial year 2018-2019. There are four major sectors in the industry among the total fifteen national income sources i.e. Quarrying \& Manufacturing and Mining, Electricity Gas \& Water, and Construction. Among all of the total 15 sources, the manufacturing sector is having the highest contribution to the Economy and the Garments sector is the role model for achieving this remarkable reputation.

In 1960 an entrepreneur launched a garment business as a small tailor named Reaz store at Dhaka. For more than a decade, the tailor started its distribution to the domestic markets. After the independence of Bangladesh (1973), the store has changed its name to M/S Reaz garments Ltd and it started exporting to foreign markets. This Ltd company was the first exporter from Bangladesh to abroad. In 1979 another company came forward, Desh Garment Ltd that was the first non-equity joint venture in the garment industry. By the end of 1982, only 47 garment industries had developed. The garments sector had increased its number to 587 in 1984-1985 and the number reached to 2900 by 1999 . Now about 4621 garment factories manufacturing in the domestic market as well as the global market. 
TABLE-2: Growth of Garment Factories in Bangladesh

\begin{tabular}{|l|l|l|l|}
\hline Year & $\begin{array}{l}\text { Number of } \\
\text { Garment } \\
\text { Factories }\end{array}$ & Year & $\begin{array}{l}\text { Number Of } \\
\text { Garment } \\
\text { Factories }\end{array}$ \\
\hline $1983-1984$ & 134 & $2013-2014$ & 4222 \\
\hline $1989-1990$ & 759 & $2014-2015$ & 4296 \\
\hline $1995-1996$ & 2353 & $2015-2016$ & 4328 \\
\hline $2001-2002$ & 3618 & $2016-2017$ & 4482 \\
\hline $2007-2008$ & 4743 & $2017-2018$ & 4560 \\
\hline $2012-2013$ & 4576 & $2018-2019$ & 4621 \\
\hline
\end{tabular}

SOURCE: Bangladesh Garment Manufacturers and Exporters Association (BGMEA)

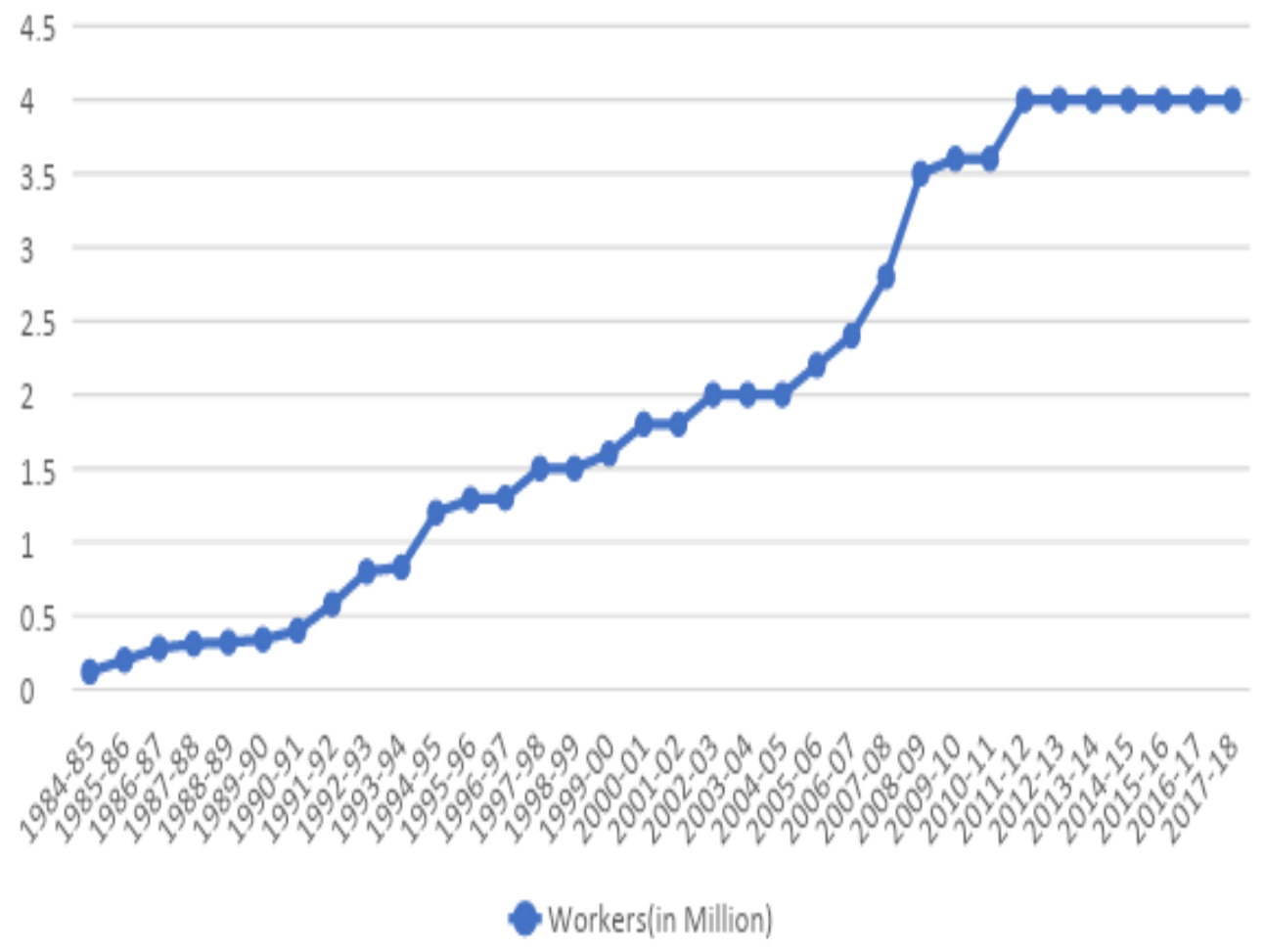

Fugure1: Number of RMG workers in Bangladesh (Source: BGMEA)

There were only 134 Garment factories in 1984, a decade later the Garment industry enlisted its number to 4222 . The proliferation of garment industries has led to an increase in the workforce in the garment sector the phenomenal growth in this sector is due to the avid support of the Government and other pioneers. This sector was also naturalized by MFA under the Uruguay Round of GATT in 1994. In Financial Year 2013-2014 the growth rate slowed down due to the crisis of raw materials.

Now Bangladesh is one of the major exporter countries all over the world. Most of the garment industries are situated in Dhaka and Chittagong with emphasis on readymade garments (RMG) production. RMG is considered as the economic barometer of the country and its contribution to the GDP almost double with that of agriculture. Bangladesh has achieved a reputation in the international market for its quality of products. According to WTO, Bangladesh has achieved a good reputation in the global market after China, EU (28). These three countries alone contribute $66.6 \%$ to the global market. 
TABLE3: Top 10 exporter of clothing 2018 (Billion Dollars)

\begin{tabular}{|l|l|l|l|l|l|l|}
\hline Exporters & $\begin{array}{l}\text { Value } \\
2018\end{array}$ & $\begin{array}{l}\text { Share in } \\
\text { world export } \\
2000\end{array}$ & $\begin{array}{l}\text { Share in world } \\
\text { export } \\
2005\end{array}$ & $\begin{array}{l}\text { Share in world } \\
\text { export } \\
2010\end{array}$ & $\begin{array}{l}\text { Share in world } \\
\text { export } \\
2018\end{array}$ & $\begin{array}{l}\text { Growth rate } \\
(2018 \mathrm{vs} 2017)\end{array}$ \\
\hline China & 158 & 18.2 & 26.6 & 36.6 & 31.3 & $-0.4 \%$ \\
\hline EU (28) & 143 & 28.7 & 31.0 & 28.4 & 28.4 & $10.6 \%$ \\
\hline Bangladesh & 32 & 2.6 & 2.5 & 4.2 & 6.4 & $11.1 \%$ \\
\hline Vietnam & 32 & 0.9 & 1.7 & 2.9 & 6.2 & $13.4 \%$ \\
\hline India & 17 & 3.0 & 3.1 & 3.2 & 3.3 & $-10.8 \%$ \\
\hline Turkey & 16 & 3.3 & 4.2 & 3.6 & 3.1 & $3.8 \%$ \\
\hline $\begin{array}{l}\text { Hong } \\
\text { Kong }\end{array}$ & 14 & -- & -- & -- & - & $-4.4 \%$ \\
\hline Indonesia & 9 & 2.4 & 1.8 & 1.9 & 1.8 & $8.7 \%$ \\
\hline Cambodia & 8 & 0.5 & 0.8 & 0.9 & 1.6 & $14.0 \%$ \\
\hline USA & 6 & 4.4 & 1.8 & 1.3 & 1.2 & $4.9 \%$ \\
\hline Above 10 & 435 & 64 & 73.5 & 83 & 83.3 & \\
\hline
\end{tabular}

Source: World Trade Organization (WTO)

Figure2: Export growth to different markets

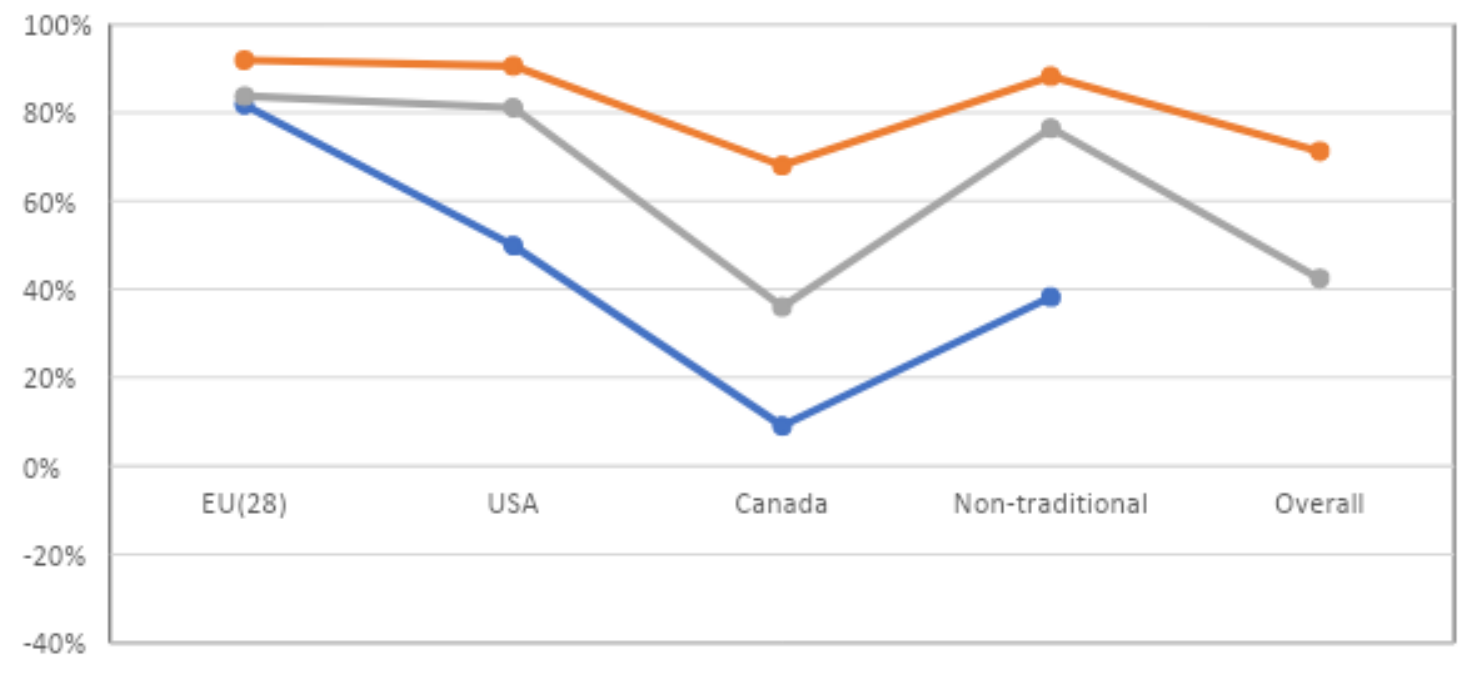

$\%$ of total export

Export growth \%,2018-19

Export growth july-january,2019-20

Figure 2; Export growth to different markets (Source: BGMEA)

Undoubtedly the garment sector in Bangladesh is the fastest-growing market, being key competitors with China, the EU (28), and Vietnam. Besides, it is evident that Bangladesh is the second leading exporter after China and the growth of export is noteworthy. According to Table-3 Bangladesh alone exported $\$ 32$ billion garment products to the foreign markets, where China, EU (28) and Vietnam exported $\$ 158$ billion, $\$ 143$ billion, $\$ 32$ billion respectively. Being a small country with less manpower it has achieved a leadership position around the world. Comparison with the past financial years, we have become acquainted every year the export rate has been increasing in the international market.

\section{A. Contribution of Garment Sector to The Economy}

The garment sector governs as a major part of the economy in Bangladesh. According to the financial year 2016-2017, the RMG industry exported $80.7 \%$ of the total export earnings and contributed 12.36 percent to the GDP. Over the last two decades, the number of factories, manufacturing rate, and contribution to GDP is voluminous. The RMG is having an eminent contribution to the national economy among all of the 15 sectors. 


\begin{abstract}
2018-19
2017-18

2016-17

2015-16

2014-15

2013-14

2012-13

2011-12

2010-11

2009-10

2008-09

2007-08

2006-07

2005-06

2004-05

2003-04

2002-03

2001-02

2000-01

1999-00

1998-99

1997-98

1996-97

1995-96

1994-95

1993-94

1992-93

1991-92

1990-91
\end{abstract}

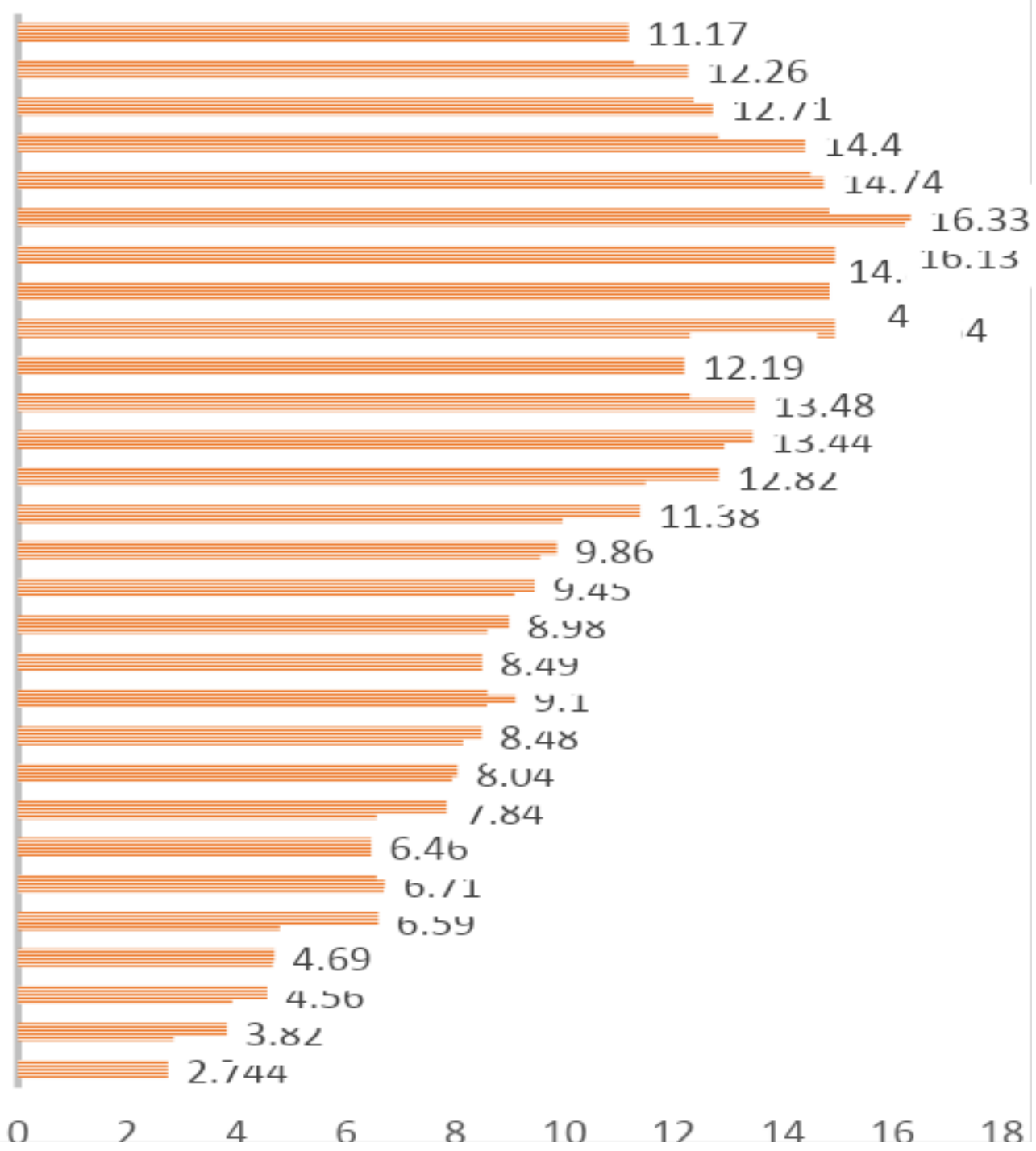

Figure3: RMG contribution to GDP in (\%) Source: Export Promotion Bureau (EPB)

The above figure indicates the contribution of the Garment sector to the Bangladesh economy. The volume of performance to GDP has been increasing from F.Y 1990-91 to 2018-19. In 1991 the participation in the Economy was only 2.744 however, it has been reached 11.17 in 2019 with plenty of conveniences. Consequently, the disbursement of the Garment Sector in the short-run and longrun is observable. But the extensive experience was drafted between 2011 to 2016. It is quite evident that the share of the Garment Sector in the GDP increases every year barring a few. With the prosperity of GDP the Per capita income also pursuing its flow. 


\section{B. Impact of Covid-19 on garments sector in Bangladesh}

Bangladesh reported its first confirmed coronavirus case on Sunday, $8^{\text {th }}$ March 2020 . Two of them were returnee from Italy and the remaining one was the family member of the infected persons. It was the first wave of coronavirus in Bangladesh. Govt ordered to cease all manufacturing activities in the Garment industry in late March as a result, the worker had to move back to their homes.

The major buyers of Bangladesh including American and European fashion firms namely GAP, ZARA, H\&M, Primark, Marks \& Spencer are slashed their imports and orders due to financial crunch \& fall in consumer spending because of the Covid-19. It is assumed that nearly 6 billion order has been cancelled. According to Bangladesh Garment Manufacturers and Exporters Association (BGMEA),982 million units of garment products which is worth $\$ 3.18$ billion had already been cancelled. On the other hand, Bangladesh depends heavily on raw materials supplied from China. According to BGMEA $40 \%$ of the machinery and spare parts for the RMG are imported from China that accounts for half of the REGULAR IMPORTED RMG raw material. The supply chain of raw materials is severely disrupted due to the unexpected outbreak of COROPNAVIRUS.

In June (2020), Only $\$ 2.12$ billion had been earned for the final month of the immediate past fiscal year. According to Bureau, Customs and Bangladesh Garment Manufacturers and Exporters Association (BGMEA) the earnings were 11.43\% lower as compared to the previous year but up 72.4 percent from the previous month. The RMG witnessed a record low in revenues; earnings from the sector stood only $\$ 0.37$ billion, the lowest since triggered booming occurred four decades ago. The following TABLE-3 shows export performance and growth rate of Financial Year 2019-2020.

Table4: Bangladesh's RMG Exports F.Y 2019-20 (In Million US\$)

\begin{tabular}{|l|l|l|l|l|l|}
\hline Month & $\begin{array}{l}\text { Export } \\
\text { Performance }\end{array}$ & Growth Rate & Month & $\begin{array}{l}\text { Export } \\
\text { Performance }\end{array}$ & Growth Rate \\
\hline July & 3,310 & $9.7 \%$ & January & 3039 & $-2.98 \%$ \\
\hline August & 2,406 & $-11.46 \%$ & February & 2784 & $-4.48 \%$ \\
\hline September & 2,341 & $-4.7 \%$ & March & 2256 & $-20.14 \%$ \\
\hline October & 2520 & $-19.79 \%$ & April & 374 & $-85.25 \%$ \\
\hline November & 2511 & -11.98 & May & 1230 & $-62.06 \%$ \\
\hline December & 2935 & $1.26 \%$ & & & \\
\hline
\end{tabular}

Source: Export Promotion Bureau (EPB)

\section{Time Series Analysis}

The indirect method of time series analysis has been used to expose the trend of Garment sector export by using 11 months of data. Here,

$$
\begin{aligned}
& \mathrm{P}=\text { constant } \\
& \mathrm{Q}=\text { slope } \\
& \mathrm{Y}=\text { Dependent variable } \\
& \mathrm{t}=\text { Time }
\end{aligned}
$$


Table5: Garment Sector Export Trend

\begin{tabular}{|l|l|l|l|l|}
\hline Months & $\begin{array}{l}\text { Export(Y) } \\
(\mathrm{mill} \$)\end{array}$ & Time(t) & $\mathrm{Y}^{*} \mathrm{t}$ & $\mathrm{t}^{2}$ \\
\hline July & 3,310 & -5 & $-16,550$ & 25 \\
\hline August & 2,406 & -4 & $-9,624$ & 16 \\
\hline September & 2,341 & -3 & $-7,023$ & 9 \\
\hline October & 2,520 & -2 & $-5,040$ & 4 \\
\hline November & 2,511 & -1 & $-2,511$ & 1 \\
\hline December & 2,935 & 0 & 0 & 0 \\
\hline January & 3,039 & 1 & 3,039 & 1 \\
\hline February & 2,784 & 2 & 5,568 & 4 \\
\hline March & 2,256 & 3 & 6,768 & 9 \\
\hline April & 374 & 4 & 1,496 & 16 \\
\hline May & 1,230 & 5 & 6,150 & 25 \\
\hline n=11 & $\sum \mathrm{Y}=25,706$ & & $\sum \mathrm{Y}^{*} \mathrm{t}=(17,727)$ & $\sum \mathrm{t}=110$ \\
\hline
\end{tabular}

$$
\begin{gathered}
\text { Now, } \\
\mathrm{P}=\sum \mathrm{Y} / \mathrm{n} \\
=25,706 / 11 \\
=2337 \\
\text { Again, } \\
\mathrm{Q}=\sum \mathrm{Y} * \mathrm{t} / \sum \mathrm{t}^{2} \\
=-17,727 / 110 \\
=-1612
\end{gathered}
$$

So, the Export business equation is-

( $\mathrm{Y}=$ Garment sector export of Bangladesh)

$$
\mathrm{Y}=2337+(-1612) * \mathrm{t}
$$

We can draw the conclusion that Covid19 brought a catastrophic impact on the Bangladesh Garment Sector sector. This pandemic has not only disrupted economic activities but also caused a migrant crisis. Thousands of workers lost their job due to deficient production and 2.28 million workers (Source: BGMEA) have tested positive. Around 850 factories are operating with fewer workers due to inadequate facilities for maintaining social distancing. They are vulnerable to getting infected while they are being recalled to report for work in these unprecedented times.

On the contrary, if the garment factories remain shut and the owners were too asked to pay the salaries in full, it would be unsustainable which will further cripple the industry. This is a pressing concern that needs to be addressed before the situation goes beyond control. The owners, therefore, have decided to continue their operations in a staggered manner and pay the workers for the work done accordingly instead of having to pay the workers without any production, which seems more pragmatic. So accordingly, the Government, Employers, and workers are cooperating to cope up with this challenging scenario and find a middle ground. If such is not the case, there would-be large-scale unemployment which would eventually push people towards poverty and hunger. About 21.8\% of people live under the poverty line in Bangladesh. The percentage is likely to increase manifold if people remain out of work. In March 2020, \$500 million has been announced as a relief package to the garment sector by the Government, and later it has been increased to $\$ 8$ Billion.

After months of lockdown economies of the EU, the USA, China and other countries are opening up slowly. Some retailers and other brands have decided to keep their shops open to facilitate some inflow of orders to the Garment sectors. The international orders are picking up in Bangladesh, Government has taken steps to oversee that the garment sectors reopen in phases so that the previous obligation of the buyers are honoured. Accordingly, the workers are coming back to the factories for work. the International Labour Organization (ILO) noted this development in Bangladesh and has urged the Government to maintain working conditions conforming to the safety norms in Covid-19 because there is always an imminent risk of spreading the virus in workplaces. 


\section{CONCLUSION}

The outbreak of Coronavirus and its impact on the garment sectors of Bangladesh has been stated. There is no conclusive evidence to determine the lifespan of COVID-19 on various surfaces (Such as Metal, Glass, Plastic) and the long-term impact on the person who has recovered is also not clear. Since it is possible for the virus to spread through the workers if they get infected (both symptomatic and asymptomatic) Bangladesh has taken some immediate measures guided by the World Trade Organization (WTO), International Labour Organization (ILO), Global health Communities, BGMEA, to adhere to the guidelines of the World Health Organization (WHO) especially to break the chain of transmission. After months of lockdown and other restrictions to curb the virus spread, various restrictions are gradually lifted except for educational institutions. Businesses are opening in a steady manner conforming to the prescribed safety measures advocated by the Government. Safety is of utmost primary concern but to mitigate the economic impact of the pandemic it is imperative to start the economy in a phased manner to improve the alarming socio-economic scenario of the people especially to avoid the perils of poverty and certain large scale starvation notably in the north part of Bangladesh. Lockdown cannot be perpetual because it will do more damage to the country in the long run which cannot be undone. Hence it can be concluded that Garment production is crucial for Economic revival but care must be taken to ensure that the health and safety of the workers are not compromised by the authorities concerned. Both the Government and the RMG industry should coordinate with each other to overcome all the hurdles.

References

1. Majumdar, A., Shaw, M., \& Sinha, S. K. (2020). COVID-19 debunks the myth of socially sustainable supply chain: A case of the clothing industry in South Asian countries. Sustainable Production and Consumption, 24, 150-155.

2. Begum, M., Farid, M. S., Barua, S., \& Alam, M. J. (2020). COVID-19 and Bangladesh: Socio-Economic Analysis Towards the Future Correspondence

3. Kabir, H., Maple, M., \& Usher, K. (2020). The impact of COVID-19 on Bangladeshi readymade garment (RMG) workers. Journal of Public Health.

4. Shimanta, M. L. R., Gope, H., \& Sumaiya, I. J. (2020). Readymade Garments Sector and Covid-19 in Bangladesh.

5. The Daily star-https://www.thedailystar.net/business/news/garment-work-orders-coming-back-slowly-1927253

6. World meter info coronavirus- https://www.worldometers.info/coronavirus/

7. BGMEA - https://www.bgmea.com.bd/home/pages/TradeInformation

8. Salim Uddin and Abu Jahed Mohammed - The Cost and Management

Vol. 35 No. 1, January-February 2007 pp. 59-70

9. Ariful Islam,Rayhan Islam and Mahmudul Hasan Siddiqui -Published online January 30, 2014,http://www.sciencepublishinggroup.com/j/ijefm), doi:11648/j.ijefm.20140201.16

10. HUANG POON and GRANGER1 CLIVE W. J. GRANGER- Journal of Economic Literature,Vol. XLI (June 2003) pp. 478-539

11. Tb news- https://tbsnews.net/economy/rmg/apparel-exports-may-have-dropped-6bn-fy20-100702

12. The diplomat https://thediplomat.com/2020/04/bangladesh-reopens-600-apparel-factories-despite-virus-risk/

13. Alak Kumar Saha,- International Journal of Science and Research (IJSR), India Online ISSN: 2319-7064

14. The daily star-https://www.thedailystar.net/business/news/rmg-export-earning-plummets-1845pc-fy-2019-20-1923913

15. Lutfor Rahman,Hridoy Gope and Israt Jahan- Preprints (www.preprints.org) | NOT PEER-REVIEWED | Posted: 28 June 2020 doi:10.20944/preprints202006.0336.v1

16. Haidar khan- Online at https://mpra.ub.uni-muenchen.de/100380/MPRA Paper $\quad$ No. 100380, posted 19 May 2020,20:37,UTC

17.The

textile

today-https://www.textiletoday.com.bd/rmg-sectors-contribution-gdp-downs-32/\#: :text=According $\% 20$ to $\% 20$ Bangladesh $\% 20 \mathrm{Garment} \% 20$ Manufacturers, fiscal $\% 20$ year $\% 20 \mathrm{of} \% 202017 \% 2 \mathrm{D} 18 . \&$ text=Although\%20the $\% 20 \mathrm{overall} \% 20 \mathrm{GDP} \% 20 \mathrm{ha}$ s,to\%20GDP\%20which\%20was\%2052.11\%25.

[18] Momotaj Begum,Md. Shaikh Farid,Swarup Barua and Dr. Mohammad Jahangir Alam-Preprints (www.preprints.org) | NOT PEER-REVIEWED | Posted: 25 April 2020 doi:10.20944/preprints202004.0458.v1

19. Orbitax - https://www.orbitax.com/news/archive.php/Bangladesh-Tax-Relief-Measures-41880

20.ResearchGate-https://www.researchgate.net/publication/328632044_Ready-Made_Garments_Sector_of_Bangladesh_Its_Contribution_and_Challenges_

21. Wickramasinghe, G. L. D., \& Wickramasinghe, V. (2017). Implementation of lean production practices and manufacturing performance. Journal of Manufacturing Technology Management

22. Ara, T., Rahman, M., Hossain, M., \& Ahmed, A. (2020). Identifying the Associated Risk Factors of Sleep Disturbance during the COVID-19 Lockdown in Bangladesh: A Web-based Survey. Frontiers in Psychiatry, 11, 966.

23.Sen, S., Antara, N., Sen, S., \& Chowdhury, S. (2020). The apparel workers are in the highest vulnerability due to COVID-19: a study on the Bangladesh Apparel Industry. Sen S, Antara N, Sen S, Chowdhury S. The apparel workers are in the highest vulnerability due to COVID-19: a study on the Bangladesh Apparel Industry. Asia Pacific J Multidiscip Res, 8(3).

24.Islam, M. S., \& Rakib, M. A. (2019). Labour Laws in the Garment Sector of Bangladesh: a Workers' View. Yuridika, 34(3), 467-482.

25. Islam, M. S., \& Rakib, M. A. (2019). Labour Laws in the Garment Sector of Bangladesh: a Workers' View. Yuridika, 34(3), 467-482.

26.World socialist web site- https://www.wsws.org/en/articles/2020/03/16/bang-m16.html

27. CNBC- https://www.cnbc.com/2020/03/27/coronavirus-bangladesh-garment-sector-faces-growing-order-cancellations.html

28. The business standard- https://tbsnews.net/economy/industry/poultry-sector-stares-over-tk1150-crore-losses-63472

This publication is licensed under Creative Commons Attribution CC BY.

http://dx.doi.org/10.29322/IJSRP.10.11.2020.p10716

WWW.ijsrp.org 


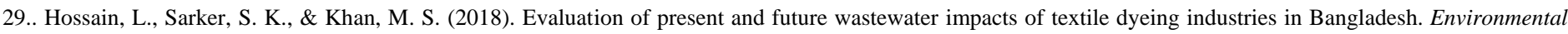
Development, 26, 23-33.

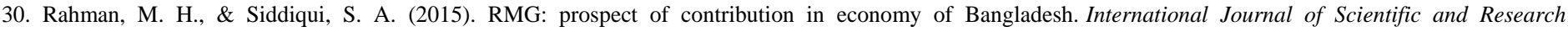
Publications, 5(9), 1-8.

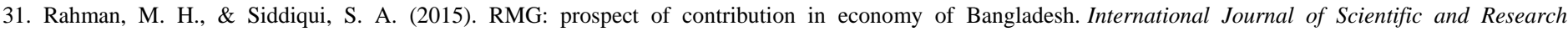
Publications, 5(9), 1-

32. Dhaka tribune https://www.dhakatribune.com/business/2019/04/26/apparel-sector-s-contribution-to-gdp-going-down-for-years

33. Textile focus http://textilefocus.com/review-outlook-2020-bangladesh-garments-textile-industry/

34.Textiletodayhttps://www.textiletoday.com.bd/rmg-sectors-contribution-gdp-downs-3-2/

\section{AUTHOR}

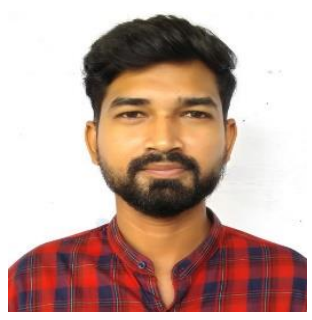

MD KHADEMUL ISLAM

M.B.A in Financial Management

Department of Commerce

Aligarh Muslim University 